\title{
Economic Growth and Budget Constraints: EU Countries Panel Data Analysis
}

\section{Petr Zimčík}

\begin{abstract}
The aim of this paper is to identify the impacts of different taxes and expenditures on economic growth. The research is focused on 20 selected European Union Member States. These countries are equally divided into four groups based on their average tax burden as presented in the World Tax Index. A comparison of fiscal attributes among these groups is important for the analysis. Annual government finance data from the years 1995 to 2012 are used for an empirical study. The indicators observed are real GDP change, the composition and volume of total government expenditures, tax quotas of individual taxes and total budget balance. These indicators are used within an endogenous growth model together with capital stock and an approximation of human capital. A panel regression with fixed effects is used as an analytic tool. The main results are that an increase in social contributions, property, production and personal income tax quotas has an adverse effect on economic growth.
\end{abstract}

Key words: Economic Growth, EU, Taxation, Government Expenditures, Panel Data

JEL Classification: H20, H50, O40

Received: 16 July 2015 / Accepted: 26 November 2015/Sent for Publication: 16 June 2016

\section{Introduction}

There is still no clear consensus among economists as to the influence of fiscal policy on economic growth. Some believe that fiscal policy has essentially no effect. Others claim that setting fiscal policy correctly can positively affect long-term growth. This paper is in part a response to this general disagreement. Furthermore, the paper observes a selection of countries, all of which are members of European Union. Although they are at different stages of supra-national integration, all these member countries have committed themselves to accept a common currency and common monetary policy, and so fiscal policy is inevitably to play an increasing role in these individual countries.

Fiscal policy's influence is even more evident if you take the current state of public finances in advanced economies into consideration. Deficit funding has become common in the advanced economics of the European Union in recent years. This fact has escalated growth in public indebtedness among EU countries.

\footnotetext{
${ }^{1}$ Masaryk University, Lipová 41a, Brno, Czech Republic, petr.zimcik@ mail.muni.cz
} 
Fiscal policy has its own unique issues. Policy-makers can choose the volume of funds that will be provided to individual departments, but their decision is bound by budget constraints. To provide sufficient financial means for their designed policy they must first collect those funds using taxes and other means. If the policy-makers cannot do so, deficit and debt arise. Evidence implies that policy-makers in most EU countries have constantly failed to keep fiscal discipline and balanced budgets. This means liabilities for future decision-making. Increasing government debts result in higher interest, which represents future obligatory expenditures and further restriction to government budgets. In many Member States of the EU, gross national debt levels are close to $100 \%$ of GDP, and some countries have even exceeded this level. ${ }^{2}$

There are two ways to lower total debt. The first is simply to acknowledge the country's incapability of paying the resulting interest, and declare bankruptcy. To avoid having to take this extreme measure, the governments of indebted countries need to alter their fiscal policy to prevent any further increase in debt level. Changes in fiscal policy can cause negative impacts on sensitive components of GDP, such as investment and private consumption. The duration of these changes can also have an effect on the process of fiscal adjustments. There could be a significant difference between making changes in fiscal policy in the form of persistent structural reforms, and making one-off budget cuts.

For this reason, fiscal policy settings must be carefully considered. To stimulate longterm economic growth, a trade-off between growth-uplifting public expenditure and adequate tax structure (distribution of revenue by type of tax) must be found. Different types of taxes and expenditures have various effects on a country's economic activity. Finding an ideal mix of these macroeconomic quantities that can solve fiscal imbalances without damaging the economic growth should be a priority for every responsible and forward-looking policy maker.

To achieve this mix, one must be able to identify the impacts of individual taxes and components of government spending. The main aim of this research paper is therefore to establish what the impacts of different types of taxation and government expenditures are on economic growth. Naturally, these impacts could differ across countries, and so the paper makes a comparison based on the different tax burdens of 20 EU Member States represented by WTI. Countries are categorised into 4 groups, each consisting of 5 countries.

\section{Literature Review}

To examine the effects of fiscal policy we first have to divide up the different components of a government budget. On the revenue side there are both distortionary and nondistortionary taxes; distortionary taxes have effect on agents' investment decisions and can thus affect the rate of economic growth, while non-distortionary taxes should not have any effect on investment or saving rates (as explained in Kneller, 1999). Predic-

\footnotetext{
2 The following EU Member States have gross government debt of over $100 \%$ of their GDP: Belgium, Greece, Ireland, Italy and Portugal. Source: Eurostat
} 
tions based on the model provided in Barro (1990) suggest that shifting from distortionary taxes towards non-distortionary taxation positively stimulates growth.

The impacts of taxation can be also distinguished based on who the taxpayer is. This division is similar to the previous one, and most direct taxes can be considered to be distortionary. ${ }^{3}$ Most economists believe that direct taxes have a stronger negative impact on growth than indirect taxes. This premise is examined in many empirical studies such as Gemell (2013), Borys (2014), Surugiu (2012) and others. Machová and Kotlán (2014a) show that indirect taxes only influence trade-off decisions between work and leisure. Direct taxes have more distortionary effects, and so shifting from them towards indirect taxes should promote economic growth while not changing the budget balance. Indirect taxation has also some distortionary tendencies, but these are not as strong as those associated with direct taxes. Components of direct taxes can influence the national output through various channels. Personal income taxes mainly influence households' disposable incomes and thus affect private consumption. Corporate taxes influence the placement of direct foreign investment. For a survey of previous studies related to tax structures and economic growth see Shinohara (2014).

Budget expenditure can be divided into productive and unproductive expenditures (Barro, 1990), based on whether they can be included in a private production function on not. If they can, then we can take them as productive and they can affect economic growth. A shift from productive expenditures to unproductive ones would be growth-inhibiting.

There is of course much debate as to which particular expenses can be labelled as productive and which taxes can be marked as distortionary. Productive expenditures include expenditures on education, health, public infrastructure, research and development and the enforcement of property rights (see Dalic, 2013). We categorise individual types of taxation and spending for the purposes of this paper later on.

As we said earlier, a budget is two-sided, and focusing only on one side is short-sighted. Budget constraints could enable the effects of changes to one side of the budget to be compensated by changes to the other. Gemell (2013) shows that an increase in productive expenditure financed by a rise in non-distortionary taxation should lead to enhanced growth. The effect that has the most negative effect on economic growth seems to be an increase in unproductive government spending that is financed by distortionary taxes. Lastly, the effects of financing productive expenditures through distortionary taxes and unproductive expenditure through non-distortionary taxes are unclear. One empirical review of the impact of fiscal composition on economic activity can be seen in Ardagna (2001).

In a key study, Kneller (1999) observed 22 OECD countries during the years 1970-1995 and examined the effects of both taxation and public expenditures. Arnold et al. (2011) analyzed the relationship between tax structure and long-term economic growth, and found that property and consumption tax had growth-friendly effects. Agell et al. (1997),

\footnotetext{
${ }^{3}$ Empirical studies use a division between direct and indirect taxes, which enables them to make an international comparison of tax structure.
} 
Dar (2002), Bergh (2010) and Afonso (2010) described the negative effects of both taxation and expenditures.

For a complete analysis of government expenditure impacts it is important to compare public and private production and examine the degree of complementarity between them. Generally speaking, in areas where public goods and private production are very similar and can be considered substitutes, public production will squeeze out private production. That results in a downturn for private firms on the market in question, as described by Irmen and Kuehnel (2009). Gwartney (1998) concludes that government expenditures undermine growth by displacing private sector activity. Regardless of the means by which expenditures are funded, whether from taxes or by borrowing, they still pose heavy displacement costs on the productive sector. Zagler and Dürnecker (2003) add that net fiscal impacts on economic growth are the sums of all positive and negative effects on overall capital productivity and returns to physical and human capital.

Wolswijk (2009) explains four types of causality between government expenditures and revenues, depending on which side of the budget is considered primary during the fiscal policy decision process. He shows that different types of decision making are adopted in each country. Some set expenditures based on the amount of money collected through taxes, while other countries plan in precisely the opposite way. This could cause problems for a complete analysis, because fiscal adjustments are made for different reasons in each country.

Attempts to improve national budget situations have been made throughout history, but not all of them were successful by far, and they had very different macroeconomic consequences. Alesina (1996), Alesina (2009) and Hagen (2002) have all examined the impacts of fiscal adjustments. A recent study by Borys (2014) demonstrated that a 1 percent GDP tax-based fiscal consolidation slows private investment growth by 0.77 percentage points. Expenditure-based consolidation of the same size however results in an improvement in private investment by 3.19 percentage points on average.

\section{Budget Constraints}

As seen in both Kneller (1999) and Bleaney (2001), economic growth $\mathrm{g}_{i, t}$ at time $t$ is determined via a function of conditioning non-fiscal variables $Y_{i, t}$ and a vector of examined fiscal variables $\mathrm{X}_{\mathrm{j}, t}$. This relationship can be formally rewritten into an econometric equation (1).

$$
\mathrm{g}_{i, t}=\alpha+\sum_{i=1}^{k} \beta_{\mathrm{i}} \mathrm{Y}_{\mathrm{i}, t}+\sum_{j=1}^{m} \gamma_{\mathrm{j}} \mathrm{X}_{\mathrm{j}, t}+\varepsilon_{i, t}
$$

If we assume that all elements of the budget are included, in a balanced budget the sum of fiscal variables will be zero:

$$
\sum_{j=1}^{m} X_{j, t}=0
$$


To avoid the problem of multicollinearity in the estimation of equation (1), at least one fiscal element must be omitted from this sum. The omitted variable is then a compensating element within the government's budget constraint. We can rewrite equation (1) as:

$$
\mathrm{g}_{i, t}=\alpha+\sum_{i=1}^{k} \beta_{\mathrm{i}} \mathrm{Y}_{\mathrm{i}, t}+\sum_{j=1}^{m-1} \gamma_{\mathrm{j}} \mathrm{X}_{\mathrm{j}, t}+\gamma_{\mathrm{m}} \mathrm{X}_{\mathrm{m}, t}+\varepsilon_{i, t}
$$

Then if we omit $\mathrm{X}_{m, t}$ to avoid the collinearity problem, the identity

$$
\sum_{j=1}^{m} \mathrm{X}_{\mathrm{j}, t}=0
$$

implies, that the actual estimated equation is:

$$
\mathrm{g}_{i, t}=\alpha+\sum_{i=1}^{k} \beta_{\mathrm{i}} \mathrm{Y}_{\mathrm{i}, t}+\sum_{j=1}^{m-1}\left(\gamma_{\mathrm{j}}-\gamma_{\mathrm{m}}\right) \mathrm{X}_{\mathrm{j}, t}+\varepsilon_{i, t}
$$

This transformation changes a null hypothesis, which is being tested. In this setting it is right to test the hypothesis $\left(\gamma_{j}-\gamma_{m}\right)=0$ rather than only testing $\gamma_{j}=0$. This is followed by a change in the interpretation of the resultant coefficients. The coefficients of each fiscal category represent the effect of a unit change in an appropriate variable offset by a unit change in the omitted variable. The omitted variable represents an implicit financing element. ${ }^{4}$ Any change in the variable selected for omission results in a change in the remaining coefficients.

\section{Data and Methodology}

As mentioned, in order to obtain relevant estimates, we first need to distinguish different types of taxation and expenditures. We use the established Classification of the Functions of Government (COFOG) to divide government expenditures into productive and unproductive categories, based on a definition of the expenditure function. The COFOG selection was inspired by Kneller (1999) and is reported in Table 1, which also shows the theoretical and empirical division of taxes. An alternative division is offered by Machová and Kotlán (2014b).

Our regression equation follows the form of equation (3). The dependent variable is the real GDP per capita of each country. The estimation is conducted with aggregate productive and unproductive expenditures and with individual types of taxes. Only the effects of individual types of taxes are presented, because when the categories of government expenditures were tested, all the coefficients were statistically insignificant. ${ }^{5}$ The fiscal element omitted from the regression is stated in each estimation.

\footnotetext{
${ }^{4}$ If we choose to omit distortionary taxes, we assume that any fiscal adjustments (for example rise of productive expenditures) are financed by an increase in distortionary taxes of the same volume to satisfy budget constraints.

${ }^{5}$ We use only productive/unproductive expenditure distinction in an analysis for that reason.
} 
Table 1 Theoretical and functional classification of taxes and expenditures

\begin{tabular}{ll}
\hline Theoretical classification & Functional classification \\
\hline Distortionary taxation & Personal income tax \\
& Corporate tax \\
& Social security contributions \\
& Property tax \\
Non-distortionary taxation & Taxes on production \\
Productive expenditures & General public services \\
& Defence \\
& Public order and safety \\
& Economic affairs \\
& Environmental protection \\
& Housing and community amenities \\
& Health \\
& Education \\
Unproductive expenditures & Recreation, culture and religion \\
& Social protection \\
\hline
\end{tabular}

Source: Kneller et al. (1999) and author's modifications

We use annual data from the years 1995-2012 from 20 selected European Union Member States. ${ }^{6}$ The explanatory variable is real GDP per capita at chained purchasing power parity in US dollars $(G D P)$. Fiscal variables were used as described in Table 1 . We use the share of the total sum of each fiscal element relative to nominal GDP. To complete our regression equation, we must also approximate human and physical capital. For physical capital we use aggregate data on gross fixed capital formation relative to nominal GDP (Cap). The share of the population enrolled in tertiary education is used to approximate human capital (Human Cap). Budget balance (Budget) and other taxes (Other) are also added into every regression to satisfy budget constraints. All the above data are used in the form of natural logarithms, to help us to interpret their effects on economic growth. The only exception to this is budget balance, which is kept in its original form; this is because most of the values have a negative sign. We cannot use logarithm because they are not defined for negative numbers.

The GDP data used is taken from Penn World Table 8.1 as the total real GDP of each country in millions of US $\$$. These real values were then converted to real per capita

\footnotetext{
${ }^{6}$ Of the 28 EU Member States, Bulgaria, Croatia and Slovenia are excluded due to the unavailability of fiscal data for these countries, while Cyprus, Latvia, Lithuania, Malta and Romania are excluded because they are not included in the World Tax Index.
} 
GDP using population statistics. All the fiscal variables originate from government finance data collected by Eurostat. ${ }^{7}$ The share of fixed capital formation is also taken from Eurostat data. The tertiary education enrollment data originate from Eurostat and are filled in using OECD statistics.

In this paper we observe $20 \mathrm{EU}$ Member States, which we divide into four groups in order to survey different tax burdens and levels of economic performance.

Tax burdens are hard to measure for entire economies. They are usually approximated by the overall tax quota, which is the total amount of tax a country collects in relation to its nominal GDP. This indicator is excellent for international comparison but cannot reflect the actual tax burden on the country's economic subjects (households, firms). Different types of economic subjects could experience different consequences as a result of income taxes, product taxes, etc.. Income taxes represent the biggest burden for one group of subjects, while in other countries taxes on products could be the main burden. So even if two countries have the same tax quotas, their economic situations could differ. Hence we decided to use an alternative indicator.

The World Tax Index ${ }^{8}$ is a multi-criteria indicator that considers both hard tax quota data and qualified expert opinion (QEO) soft data, ${ }^{9}$ as Machová and Kotlán (2012) explain. The WTI denotes the total value of the tax burden compared to other observed countries. It does not only emphasize the overall tax quota but also includes other important, above all legal, aspects such as the progressivity of taxation, the administrative demands of tax collection, the extent of tax exceptions, deductions, tax credits, etc.

The countries examined are divided into four groups by their average WTI index during the period 2000-2012. The WTI dataset is presented in Appendix 1. The higher the number, the greater the tax burden in a given country is compared to other countries. The distribution of countries is shown in Table 2.

Table 2 Distribution of countries based on WTI

\begin{tabular}{cccc}
\hline Group I & Group II & Group III & Group IV \\
\hline Denmark & Netherlands & Luxembourg & Spain \\
Hungary & Austria & United Kingdom & Portugal \\
Belgium & Germany & France & Greece \\
Finland & Poland & Estonia & Ireland \\
Sweden & Italy & Czech Republic & Slovakia \\
\hline
\end{tabular}

Source: Author, based on WTI data

\footnotetext{
${ }^{7}$ The only handicap in this data was missing values for property tax in Finland.

${ }^{8}$ http://www.worldtaxindex.com/

${ }^{9}$ QEO is gained annually from a questionnaire survey of tax experts from a number of universities and international institutions across the world.
} 
Group I contains the countries with the highest tax burdens and group IV those with the lowest. The order within the groups is from highest to lowest based on the individual countries' average WTI score.

To complete our analysis we use a panel data regression. Panel data provide an excellent opportunity to study data internationally and over a long time horizon, which is needed in order to assess impacts on long-term growth. In order to obtain unbiased results, we first check the stationarity of our time-series data using an ADF test similar as in Levin (2002). The dependent variable $(G D P)$ and explanatory variables (Cap), (Human cap) and (Other), as well as some of the fiscal variables, indicate the presence of a unit-root in all the country groups. This problem with non-stationarity is treated by differentiating all variables. Another round of testing shows that this procedure has fixed the non-stationarity problem. Other explanatory variables only show nonstationarity in certain groups. To fix this and to preserve consistency and comparability between the groups, all the remaining variables are also differentiated. Working with differences instead of the original variables changes the interpretation of the coefficients. ${ }^{10}$ We use the econometric software Gretl to calculate our estimates.

\section{Empirical results}

We calculate our coefficients using a panel regression with fixed-effects. This method is particularly efficient when individual units have different features as it enables us to anticipate different intercepts for each unit. For that reason, a pooled OLS cannot be used. We tested a common intercept for all units, which resulted in the rejection of common intercept hypothesis and confirmed that a polled OLS would be biased estimator. We also performed a Hausmann test for all four regressions; in three of the four, the hypothesis of an uncorrelated intercept was rejected. ${ }^{11}$ Hence a panel regression with fixed-effects is more efficient and less biased than a random effect regression.

When interpreting the results, the coefficients' signs are more important than their actual values. A negative coefficient indicates that change to the variable in question has a negative effect on growth, and vice-versa.

Table 3 reports our estimation with unproductive expenditures as the omitted variable and source of changes for all other variables. The log difference in per capita GDP is the dependent variable. This follows the procedure set out by Kneller (1999). We modified this by examining effects of each category of distortionary taxes. Non-distortionary taxes only represent taxes on production and so these are not decomposed any further. The theoretical framework presented in Barro (1990) and some evidence in Kneller (1999) suggests that (Cap) and (Human Cap) have positive signs in addition to (Productive). Distortionary taxes should have a negative sign and the sign of (Non-distor tax) is theoretically uncertain.

\footnotetext{
${ }^{10}$ Instead of presenting percentage change, coefficients represent percentage point change.

${ }^{11}$ To preserve consistency across all country groups, we use a regression with fixed-effects.
} 
Table 3 Regression with Unproductive as omitted variable ${ }^{12}$

\begin{tabular}{|c|c|c|c|c|}
\hline Variable & Group I & Group II & Group III & Group IV \\
\hline \multirow[t]{2}{*}{ Constant } & $0.012 * * *$ & $0.017 * * *$ & $0.020 * * *$ & $0.024 * * *$ \\
\hline & $(3.204)$ & (14.695) & $(9.480)$ & (14.561) \\
\hline \multirow[t]{2}{*}{ Cap } & $0.181 * * *$ & $0.224 * * *$ & $0.244 * * *$ & $0.314 * * *$ \\
\hline & $(4.429)$ & $(4.456)$ & $(4.866)$ & $(6.925)$ \\
\hline \multirow[t]{2}{*}{ Human Cap } & 0.052 & -0.003 & $0.068 * * *$ & $0.305 * * *$ \\
\hline & $(0.465)$ & $(-0.064)$ & $(3.650)$ & $(2.796)$ \\
\hline \multirow[t]{2}{*}{ Budget } & 0.002 & 0.005 & 0.006 & 0.005 \\
\hline & (1.321) & (1.353) & $(0.984)$ & (1.189) \\
\hline \multirow[t]{2}{*}{ Non-distor tax } & $-0.250 * * *$ & -0.026 & -0.220 & $-0.148 * * *$ \\
\hline & $(-7.839)$ & $(-0.351)$ & $(-1.672)$ & $(-3.685)$ \\
\hline \multirow[t]{2}{*}{ Property tax } & 0.003 & $-0.087 * * *$ & $-0.050 * * *$ & $-0.069 * *$ \\
\hline & $(0.263)$ & $(-3.677)$ & $(-6.136)$ & $(-2.215)$ \\
\hline \multirow[t]{2}{*}{ Income tax } & -0.045 & $-0.101 * *$ & -0.149 & $-0.154 * * *$ \\
\hline & $(-0.538)$ & $(-2.415)$ & $(-1.309)$ & $(-3.019)$ \\
\hline \multirow[t]{2}{*}{ Corporate tax } & 0.009 & 0.017 & 0.017 & 0.074 \\
\hline & $(0.755)$ & (1.193) & $(0.498)$ & $(1.296)$ \\
\hline \multirow[t]{2}{*}{ Soc. contr. } & 0.012 & $-0.285 * * *$ & $-0.626^{* *}$ & -0.001 \\
\hline & $(0.763)$ & $(-7.535)$ & $(-2.103)$ & $(-0.019)$ \\
\hline \multirow[t]{2}{*}{ Other } & $-0.015^{* *}$ & 0.004 & -0.008 & -0.007 \\
\hline & $(-2.284)$ & $(0.108)$ & $(-1.019)$ & $(-0.284)$ \\
\hline \multirow[t]{2}{*}{ Productive } & -0.080 & $0.208 * * *$ & 0.147 & 0.226 \\
\hline & $(-0.450)$ & $(2.710)$ & $(0.740)$ & (1.630) \\
\hline $\mathrm{R}^{2}$ & 0.320 & 0.466 & 0.388 & 0.575 \\
\hline F-statistic & 1.843 & 3.309 & 2.244 & 5.613 \\
\hline DW & 1.147 & 1.211 & 1.182 & 1.409 \\
\hline Number of obs. & 73 & 78 & 78 & 78 \\
\hline
\end{tabular}

Source: Author's calculations

From Table 3 it is evident that changes in capital stock and human capital in groups III and IV have a significant positive influence. Changes in budget balance appear to be insignificant in all four groups and their effect is close to zero. Changes in nondistortionary taxes have a negative impact in all four groups but this impact is only significant in groups I and IV. Changes in individual distortionary taxes meet expecta-

\footnotetext{
${ }^{12}$ Appropriate t-statistics for each variable are listed in parentheses. The number of stars next to each coefficient represents significance level: $(*) 10 \%,(* *) 5 \%$ and $(* * *) 1 \%$. Robust (HAC) standard errors were used in the estimation. The same applies in Table 4.
} 
tions, with the exception of corporate taxes. In all four groups changes in the corporate tax quota are insignificant but directly related to economic growth. Productive expenditures boost economic growth in the lower three groups but this boost is only significant in group two.

Table 4 Regression with Non-distort tax as omitted variable

\begin{tabular}{|c|c|c|c|c|}
\hline Variable & Group I & Group II & Group III & Group IV \\
\hline Constant & $\begin{array}{c}0.013 * * * \\
(2.775)\end{array}$ & $\begin{array}{c}0.015 * * * \\
(9.629)\end{array}$ & $\begin{array}{c}0.022 * * * \\
(7.745)\end{array}$ & $\begin{array}{c}0.025 * * * \\
(14.144)\end{array}$ \\
\hline Cap & $\begin{array}{c}0.200 * * * \\
(3.673)\end{array}$ & $\begin{array}{l}0.111 * \\
(1.728)\end{array}$ & $\begin{array}{l}0.185 * * \\
(2.499)\end{array}$ & $\begin{array}{c}0.281 * * * \\
(7.269)\end{array}$ \\
\hline Human Cap & $\begin{array}{c}0.066 \\
(0.573)\end{array}$ & $\begin{array}{c}0.021 \\
(0.550)\end{array}$ & $\begin{array}{c}0.063 * * * \\
(3.098)\end{array}$ & $\begin{array}{c}0.275 * * * \\
(2.879)\end{array}$ \\
\hline Budget & $\begin{array}{c}0.002 \\
(0.600)\end{array}$ & $\begin{array}{l}-0.000 \\
(-0.056)\end{array}$ & $\begin{array}{l}-0.003 \\
(-0.395)\end{array}$ & $\begin{array}{l}-0.000 \\
(-0.036)\end{array}$ \\
\hline Property tax & $\begin{array}{l}-0.003 \\
(-0.354)\end{array}$ & $\begin{array}{c}-0.084 * * * \\
(-3.606)\end{array}$ & $\begin{array}{l}-0.015 \\
(-1.375)\end{array}$ & $\begin{array}{c}-0.060 * * \\
(-2.171)\end{array}$ \\
\hline Income tax & $\begin{array}{l}-0.032 \\
(-0.311)\end{array}$ & $\begin{array}{l}-0.048 \\
(-1.116)\end{array}$ & $\begin{array}{l}-0.053 \\
(-0.457)\end{array}$ & $\begin{array}{l}-0.120 * \\
(-1.716)\end{array}$ \\
\hline Corporate tax & $\begin{array}{c}0.008 \\
(0.693)\end{array}$ & $\begin{array}{l}-0.003 \\
(-0.116)\end{array}$ & $\begin{array}{c}0.026 \\
(0.900)\end{array}$ & $\begin{array}{c}0.073 \\
(1.316)\end{array}$ \\
\hline Soc. contr. & $\begin{array}{l}0.025^{*} \\
(1.781)\end{array}$ & $\begin{array}{c}-0.202 * * * \\
(-3.932)\end{array}$ & $\begin{array}{l}-0.351 \\
(-1.168)\end{array}$ & $\begin{array}{c}0.045 \\
(0.575)\end{array}$ \\
\hline Other & $\begin{array}{l}-0.017 \\
(-1.468)\end{array}$ & $\begin{array}{c}0.010 \\
(0.324)\end{array}$ & $\begin{array}{l}-0.009 \\
(-1.123)\end{array}$ & $\begin{array}{l}-0.009 \\
(-0.378)\end{array}$ \\
\hline Productive & $\begin{array}{l}-0.031 \\
(-0.169)\end{array}$ & $\begin{array}{c}0.083 \\
(0.828)\end{array}$ & $\begin{array}{l}-0.090 \\
(-0.389)\end{array}$ & $\begin{array}{c}0.059 \\
(0.454)\end{array}$ \\
\hline Unproductive & $\begin{array}{l}-0.021 \\
(-0.071)\end{array}$ & $\begin{array}{l}-0.474 * \\
(-1.852)\end{array}$ & $\begin{array}{l}-0.454 \\
(-1.351)\end{array}$ & $\begin{array}{l}-0.087 * \\
(-1.758)\end{array}$ \\
\hline$\overline{\mathrm{R}^{2}}$ & 0.290 & 0.509 & 0.440 & 0.567 \\
\hline F-statistic & 1.603 & 3.929 & 2.775 & 5.432 \\
\hline DW & 1.196 & 1.141 & 1.249 & 1.372 \\
\hline Number of obs. & 73 & 78 & 78 & 78 \\
\hline
\end{tabular}

Source: Author's calculations 
If we examine Table 3 we see that there are no clear sequences or order to the coefficients within the groups. The division of countries was targeted to show any diversity, but none is evident based on the empirical results in Table 3.

Table 4 shows a further panel regression, this time with non-distortionary taxes as the omitted variable. Theory predicts the same signs for the coefficients as in the previous case, and an uncertain sign for unproductive expenditures. ${ }^{13}$

The results shown in Table 4 are consistent with the theoretical framework, as regards Cap, Human cap and most distortionary taxes. Budget is insignificant in all four groups, with coefficients very close to zero. Productive expenditures are also insignificant in all groups, although its sign varies. Unproductive expenditures have a negative sign in all groups but significance in only two of them. As in Table 3, corporate tax quotas are shown to have a positive relationship with economic growth.

The results for social contributions reveal one irregularity. It appears that in groups II and III (Table 3) the estimates are significant and negative, which was predicted by theory. However, in group I and IV the signs are positive (although these results were not significant in Table 3 and 4).

\section{Conclusion}

The aim of this paper was to identify the impacts of different types of taxation and government expenditures on economic growth. To achieve this, a fixed-effects panel data regression was estimated for $20 \mathrm{EU}$ Member States, divided into four groups based on their tax burden as approximated by the World Tax Index.

The empirical results in Tables 3 and 4 provide some evidence of consistency with the theoretical framework. They suggest that most distortionary taxes have an indirect relationship to economic growth; this has also been demonstrated in many recent studies. However, our results reveal that corporate taxes are an exception to this; they have an insignificant but positive relationship to economic growth. Our results also show that non-distortionary (production) taxes and unproductive expenditures have negative impacts on economic growth, while previous theory and early studies suggested that these variables have an ambiguous effect.

Furthermore, we have found that changes in non-fiscal variables, specifically capital stock and human capital approximation have a positive and in most cases significant effect on per capita economic growth, as we expected. More interestingly, this effect is clearly stronger in countries with lower tax burdens (groups III and IV).

Although our division of the studied countries into four groups based on WTI scores provided estimates comparable with other studies and theory, we did not find evidence of any upwards or downwards changes in the fiscal estimates among the groups. We anticipated a visible trend based on the overall tax burden expressed by WTI. If some of

\footnotetext{
${ }^{13}$ In Table 3 non-distortionary taxes replace unproductive expenditures as a source of change in the independent variables.
} 
this sequence was present in results we could determine diverse effects of taxation and expenditures due to different level of overall tax burden. However no such trend was found in our estimates.

Our results have a number of implications for policy makers. An increase in individual, production and property taxes and social contributions together with a rise in unproductive expenditures would have an adverse effect on economic growth. The current situation of deficits and debt accumulation calls for fiscal tightening. Policy makers should focus on reforms that lower overall expenditures (preferable unproductive ones) rather than increasing taxes.

Acknowledgement: I would like to thank Vlastimil Reichel for his helpful advice and also to the technical editor and two anonymous referees for their useful suggestions and comments.

Funding: This paper was created as a part of specific research project no. MUNI/A/1223/2014 at Masaryk University.

Disclosure statement: No potential conflict of interest was reported by the author.

\section{References}

AFONSO, A., and D. FURCERI. (2008). Government Size, Composition, Volatility and Economic Growth. ECB Working paper No. 849.

AGELL, J., T. LINDH and H. OHLSSON. (1997). Growth and the public sector: A critical review essay, European Journal of Political Economy Vol. 13, pp. 33-52.

ALESINA, A., and R. PEROTTI. (1996). Fiscal Adjustments in OECD countries: composition and macroeconomic effect. NBER Working paper 5730.

ALESINA, A., and R. PEROTTI. (2009). Large changes in fiscal policy: taxes versus spending. NBER Working paper 15438.

ARDANGA, S. (2001). Fiscal Policy Compostition, Public Debt, and Economic Activity. Public Choice, Vol. 109, pp. 301-325. DOI: 10.1023/A:1013021004195

ARNOLD, J., B. BRYS, CH. HEADY, C. JOHANSSON, C. SCHWELLNUS, and L. VARTIA. (2011). Tax Policy For Economic Recovery and Growth, The Economic Journal, Vol. 121, pp. 59-80. DOI: 10.1111/j.1468-0297.2010.02415.X

BARRO, R. (1990). Government spending in a simple model of endogenous growth. Journal of Political Economy, Vol. 98, pp. 103-117. DOI: $10.1086 / 261726$

BERGH, A., and M. KARLSSON. (2010). Government Size and Growth: Accounting for Economic Freedom and Globalization. Public Choice. Vol. 142, No. 1/2, pp. 195213. DOI: $\underline{10.1007 / \mathrm{s} 11127-009-9484-1}$

BLEANEY, M., N. GEMELL, and R. KNELLER. (2001). Testing the Endogenous Growth Model: Public Expenditure, Taxation, and Growth ove the Long Run. The Canadian Journey of Economics 34, pp. 36-57. DOI: 10.1111/0008-4085.00061 
BORYS, P., P. CIZKOWITZ and A. RZOŃCA (2014). Panel Data Evidence on the Effects of Fiscal Policy Shocks in the EU New Member States, Fiscal Studies, Vol. 35, No. 2, pp. 189-224. DOI: $\underline{10.1111 / j .1475-5890.2014 .12028 . x}$

DALIC, M. (2013). Fiscal policy and growth in new member states of the EU: A panel data analysis. Financial theory and practice.

DAR, A. and S. AMIRKHALKHALI (2002). Government Size, Factor Accumulation, Total Factor Productivity and Economic Growth: Evidence from OECD Countries. Journal of Policy Modeling. pp. 679-692. DOI: 10.1016/S0161-8938(02)00163-1

GEMMELL, N., and J. AU (2013). Government size, fiscal policy and the level and growth of output: A review of recent evidence, Journal of the Asia Pacific Economy, Vol. 18, No.2, pp: 203-229 DOI: 10.1080/13547860.2013.777535

GWARTNEY, J., R. LAWSON, and R. HOLCOMBE. (1998). The size and functions of government and economic growth. Joint Economic Committee, Vol. 5.

HAGEN, J., A. HALLET, and R. STRAUCH. (2002). Budgetary Consolidation in Europe: Quality, Economic Conditions, Persistence. Journal of the Japanese and International Economies, Vol. 16, pp. 512-535.

IRMEN, A., and J. KUEHNEL. (2009). Productive Government Expenditure and Economic Growth. Journal of Economic Surveys, Vol. 23, pp. 692-733. DOI: 10.1111/j.1467-6419.2009.00576.x

KNELLER, R., M. BLEANEY, and N. GEMELL. (1999). Fiscal Policy and growth: evidence from OECD countries. Journal of Public Economics, Vol. 74, pp. 171-190. DOI: $\underline{10.1016 / \mathrm{S} 0047-2727(99) 00022-5}$

LEVIN, A., C. LIN, and C. CHU. (2002). Unit Root Tests in Panel Data: Asymptotic and Finite-Sample Properties. Journal of Econometrics, Vol. 108, pp. 1-24. DOI: 10.1016/S0304-4076(01)00098-7

MACHOVÁ, Z., and I. KOTLÁN. (2013). World Tax Index: New Methodology for OECD Countries, 2000-2010. DANUBE: Law and Economics Review, Vol. 4, 165-179. DOI: $10.2478 /$ danb-2013-0008

MACHOVÁ, Z., and I. KOTLÁN. (2014a). Do taxes matter for long-run growth? Still an actual problem of fiscal policy, Actual Problems of Economics, No. 7,pp. 418-428.

MACHOVÁ, Z., and I. KOTLÁN. (2014b). Expenditures on Collective and Individual Services: Discussion on the Classification of Government Expenditures with Regard to their Inclusion into Growth Models. Law and Economics Review, Vol. 5, pp. 287-296. DOI: $10.2478 /$ danb-2014-0016

PETRU-OVIDIU, M. (2015). Tax composition and economic growth. A panel-model approach for Eastearn Europe. Economy Series, Vol. 2, pp. 89-101

SCHNEIDER, F. (2014). In the Shadow of the State - the Informal Economy and Informal Economy Labor Force. Law and Economics Review, Vol. 5, pp. 227-248. DOI: $\underline{10.2478 / \text { danb-2014-0013 }}$ 
SHINOHARA, M. (2014). Tax Structure and Economic Growth - A Survey of Empirical Analyses, Institute of Economic Research Chuo University, Discussion Paper No. 217 .

SURUGIU, M., and C. SURUGIU. (2012). Tax competition, harmonization and development: Challenges and consequences. Argumenta Oeconomica, Vol.1, pp. 139-154

WOLSWIJK, G. (2009). Causality Between Government Revenues and Spending in Europe. The Icfai University Journal of Public Finance, Vol. 7, pp. 6-24.

ZAGLER, M., and G. DÜRNECKER. (2003). Fiscal Policy and Economic Growth. Journal of Economic Surveys, Vol. 17, pp. 397-418. DOI: 10.1111/1467-6419.00199 


\section{Appendix 1: World Tax Index 2000-2012}

\begin{tabular}{|c|c|c|c|c|c|c|c|c|c|c|c|c|c|c|c|c|c|c|c|c|c|}
\hline$\frac{n}{0}$ & 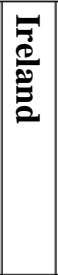 & $\begin{array}{l}\Omega \\
0 \\
0 \\
0\end{array}$ & 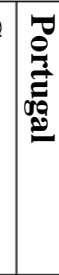 & 告 & 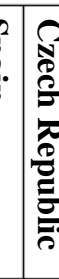 & & & 可 & 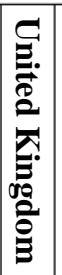 & 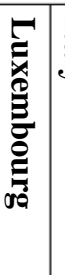 & $\overrightarrow{\overrightarrow{\tilde{J}}}$ & 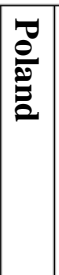 & 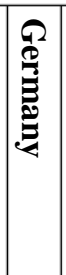 & 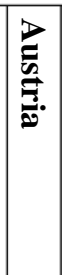 & 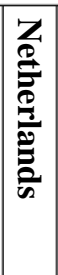 & 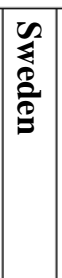 & & 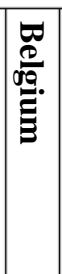 & 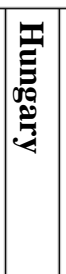 & & 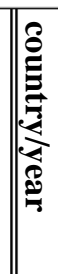 \\
\hline in & $\begin{array}{l}0 \\
\stackrel{0}{u} \\
u \\
u\end{array}$ & 品 & 总 & $\stackrel{0}{0}$ & $\stackrel{\infty}{\infty}$ & & $\begin{array}{l}0 \\
u \\
t\end{array}$ & $\begin{array}{l}\circ \\
\dot{8}\end{array}$ & $\begin{array}{l}0 \\
8 \\
8\end{array}$ & $\stackrel{\circ}{\circ}$ & $\begin{array}{l}\circ \\
\vdots \\
0\end{array}$ & $\begin{array}{l}\circ \\
\dot{8}\end{array}$ & 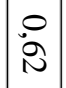 & $\begin{array}{l}0 \\
\dot{\omega} \\
\dot{\omega}\end{array}$ & \begin{tabular}{|l|}
$\circ$ \\
$\stackrel{0}{\omega}$ \\
$\dot{\omega}$
\end{tabular} & \begin{tabular}{l}
0 \\
\hdashline \\
0
\end{tabular} & $\stackrel{\circ}{\doteq}$ & $\stackrel{O}{\stackrel{N}{N}}$ & $\begin{array}{l}0 \\
\stackrel{\sim}{A} \\
\end{array}$ & 겅 & 紫 \\
\hline 怘 & $\begin{array}{l}0 \\
\text { 岕 } \\
\mathrm{N}\end{array}$ & $\stackrel{0}{\stackrel{u}{u}}$ & 品 & : & i & & $\begin{array}{l}0 \\
u \\
t\end{array}$ & $\mid \begin{array}{l}0 \\
ن \\
ن \\
y\end{array}$ & 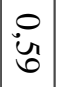 & $\begin{array}{l}\circ \\
0 \\
0\end{array}$ & $\begin{array}{l}0 \\
0 \\
0\end{array}$ & $\begin{array}{l}\circ \\
8 \\
8\end{array}$ & $\begin{array}{l}0 \\
\dot{8}\end{array}$ & $\dot{0}$ & $\begin{array}{l}\circ \\
2 \\
2\end{array}$ & : & $\stackrel{0}{\Xi}$ & $\stackrel{0}{\stackrel{N}{N}}$ & $\begin{array}{l}0 \\
\dot{u} \\
u\end{array}$ & $\stackrel{0}{\infty}$ & 领 \\
\hline$\stackrel{\infty}{\infty}$ & \begin{tabular}{|l|}
0 \\
$\stackrel{0}{*}$ \\
$\dot{0}$
\end{tabular} & $\underset{\sim}{\stackrel{0}{u}}$ & 品 & 号 & $\stackrel{0}{0}$ & & & $\begin{array}{ll}0 \\
ن \\
y \\
y\end{array}$ & 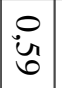 & 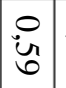 & $\begin{array}{l}0 \\
\dot{8}\end{array}$ & \begin{tabular}{l}
0 \\
0 \\
\hdashline
\end{tabular} & 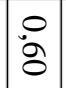 & 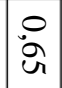 & $\begin{array}{l}0 \\
9 \\
9\end{array}$ & \begin{tabular}{l|}
$\circ$ \\
$\dot{\infty}$ \\
$\infty$
\end{tabular} & $\begin{array}{l}\circ \\
\stackrel{0}{0}\end{array}$ & $\stackrel{\circ}{\stackrel{O}{N}}$ & 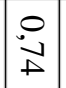 & $\stackrel{O}{y}$ & 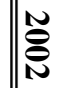 \\
\hline$\hat{b}$ & \begin{tabular}{|l|} 
\\
$\stackrel{0}{*}$ \\
$\dot{t}$
\end{tabular} & 品 & 点 & $\begin{array}{l}0 \\
\text { un }\end{array}$ & 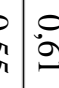 & & & $\begin{array}{l}0 \\
\text { ing } \\
\end{array}$ & \begin{tabular}{l|}
$\circ$ \\
8 \\
8
\end{tabular} & \begin{tabular}{l|}
$\circ$ \\
$\dot{8}$
\end{tabular} & 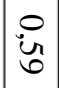 & \begin{tabular}{l}
$\circ$ \\
\hdashline \\
\hdashline
\end{tabular} & $\begin{array}{l}\circ \\
0 \\
0\end{array}$ & $\begin{array}{l}0 \\
\dot{u}\end{array}$ & $\begin{array}{l}\circ \\
9 \\
9\end{array}$ & : & $\begin{array}{l}\circ \\
\ddot{d}\end{array}$ & $\stackrel{0}{\ominus}$ & $\begin{array}{l}0 \\
\dot{\omega} \\
\dot{\omega}\end{array}$ & $\stackrel{0}{0}$ & 胥 \\
\hline 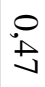 & \begin{tabular}{|l|}
0 \\
$\stackrel{0}{*}$ \\
$\dot{0}$
\end{tabular} & 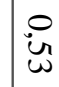 & 总 & : & i & & $\begin{array}{l}0 \\
\tilde{\sigma} \\
\sigma\end{array}$ & $\begin{array}{l}0 \\
\dot{u} \\
\infty\end{array}$ & $\begin{array}{l}\circ \\
8 \\
8\end{array}$ & \begin{tabular}{l|}
$\circ$ \\
$\dot{8}$
\end{tabular} & 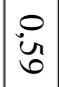 & $\begin{array}{l}\circ \\
8 \\
8\end{array}$ & $\begin{array}{l}\circ \\
0 \\
0\end{array}$ & 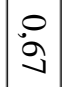 & $\begin{array}{l}\circ \\
\infty \\
\infty\end{array}$ & $\stackrel{0}{\circ}$ & $\begin{array}{l}\circ \\
\stackrel{0}{0}\end{array}$ & $\stackrel{0}{\Xi}$ & $\begin{array}{l}0 \\
\stackrel{\sim}{u} \\
u\end{array}$ & $\stackrel{0}{0}$ & 零 \\
\hline f & $\begin{array}{l}0 \\
\dot{y} \\
0\end{array}$ & 巟 & 点 & 诗 & in & & $\begin{array}{l}0 \\
u \\
u\end{array}$ & \begin{tabular}{|l|}
0 \\
$\dot{2}$ \\
$\infty$
\end{tabular} & \begin{tabular}{l|}
0 \\
$\stackrel{0}{6} \mathbf{b}$ \\
\end{tabular} & 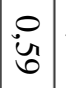 & 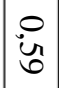 & \begin{tabular}{l}
$\circ$ \\
0 \\
\hdashline
\end{tabular} & 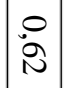 & $\because$ & $\begin{array}{l}0 \\
9 \\
9\end{array}$ & $\stackrel{0}{=}$ & $\begin{array}{ll}\circ \\
\stackrel{0}{0}\end{array}$ & $\stackrel{\circ}{\stackrel{\sim}{\omega}}$ & $\begin{array}{l}\circ \\
\stackrel{\partial}{a}\end{array}$ & $\stackrel{0}{\infty}$ & 䇾 \\
\hline : & \begin{tabular}{|l|} 
\\
$\stackrel{0}{*}$ \\
$\dot{t}$
\end{tabular} & $\underset{\not}{\circ}$ & :̈ & 诗 & $\begin{array}{l}0 \\
\text { in }\end{array}$ & & $\begin{array}{l}0 \\
\text { un } \\
\text { un }\end{array}$ & $\begin{array}{ll}0 \\
\text { in } \\
\text { in }\end{array}$ & 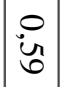 & \begin{tabular}{l|}
0 \\
$\dot{y}$ \\
$y$
\end{tabular} & $\stackrel{\circ}{8}$ & $\begin{array}{ll}\circ \\
\end{array}$ & $\begin{array}{l}0 \\
0 \\
0\end{array}$ & $\stackrel{\circ}{9}$ & \begin{tabular}{l|}
$\circ$ \\
$\infty$ \\
$\infty$
\end{tabular} & $\stackrel{0}{\partial}$ & $\begin{array}{ll} \\
8 \\
\end{array}$ & $\stackrel{0}{\omega}$ & \begin{tabular}{|l|} 
\\
9 \\
9
\end{tabular} & $\begin{array}{l}0 \\
\infty \\
\infty\end{array}$ & 䓵 \\
\hline $\begin{array}{l}0 \\
\stackrel{0}{*}\end{array}$ & $\begin{array}{l}0 \\
\stackrel{0}{\infty} \\
\infty \\
\infty\end{array}$ & 总 & 品 & $\begin{array}{l}0 \\
\infty\end{array}$ & $\begin{array}{l}0 \\
0\end{array}$ & & 并 & $\begin{array}{l}0 \\
\dot{y} \\
y\end{array}$ & 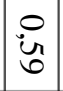 & \begin{tabular}{|c|}
0 \\
$\dot{i}$ \\
$\infty$
\end{tabular} & $\stackrel{\circ}{0}$ & $\stackrel{\circ}{\circ}$ & $\begin{array}{l}0 \\
\dot{1}\end{array}$ & $\stackrel{\circ}{9}$ & $\begin{array}{l} \\
2 \\
2\end{array}$ & O̊ & \begin{tabular}{|l|} 
\\
$\dot{\infty}$
\end{tabular} & $\stackrel{\circ}{\stackrel{N}{N}}$ & $\begin{array}{l} \\
0 \\
0\end{array}$ & $\ddot{\alpha}$ & 㑹 \\
\hline $\begin{array}{l}\circ \\
\pm \\
\pm\end{array}$ & \begin{tabular}{|l|}
0 \\
$\stackrel{0}{\infty}$ \\
$\infty$
\end{tabular} & 見 & $\underset{\text { ü }}{0}$ & : & $\ddot{y}$ & & $\begin{array}{ll}0 \\
\text { un } \\
\sigma\end{array}$ & $\begin{array}{l}0 \\
0 \\
i \\
\infty\end{array}$ & 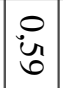 & $\mid$\begin{tabular}{l|}
0 \\
$\dot{i v y}$ \\
$v$
\end{tabular} & 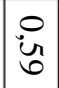 & $\begin{array}{l}0 \\
\text { ing } \\
\end{array}$ & $\begin{array}{l}\circ \\
\vdots \\
0\end{array}$ & $\stackrel{\circ}{9}$ & $\begin{array}{l}\circ \\
9 \\
9\end{array}$ & $\begin{array}{l}0 \\
\dot{9}\end{array}$ & \begin{tabular}{l|}
$\circ$ \\
8 \\
\end{tabular} & $\stackrel{O}{\sim}$ & \begin{tabular}{|l|} 
\\
0 \\
9
\end{tabular} & $\stackrel{0}{a}$ & $\mathcal{N}_{\infty}^{N}$ \\
\hline $\begin{array}{l}\circ \\
\stackrel{\infty}{\infty}\end{array}$ & \begin{tabular}{|l|l|} 
\\
\hdashline \\
+ \\
\end{tabular} & i & $\begin{array}{l}0 \\
\dot{u n} \\
\perp\end{array}$ & $\begin{array}{l}0 \\
\infty\end{array}$ & $\begin{array}{ll}0 \\
0 \\
0\end{array}$ & & $\begin{array}{l}0 \\
\dot{\alpha} \\
\dot{\omega}\end{array}$ & $\begin{array}{l}0 \\
\text { ind }\end{array}$ & 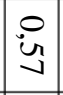 & $\begin{array}{ll}0 \\
\text { in } \\
\text { v }\end{array}$ & 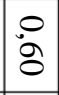 & $\begin{array}{l}0 \\
8 \\
8\end{array}$ & \begin{tabular}{|l|}
$\circ$ \\
0 \\
\end{tabular} & 今. & $\begin{array}{l}0 \\
9 \\
9\end{array}$ & $\therefore$ & \begin{tabular}{|l|} 
\\
$\infty$ \\
$\infty$
\end{tabular} & $\stackrel{0}{\underset{\omega}{\omega}}$ & \begin{tabular}{|l|}
$\circ$ \\
8 \\
0
\end{tabular} & $\begin{array}{l}0 \\
\alpha \\
\alpha\end{array}$ & $\widetilde{\tilde{O}}$ \\
\hline$+\infty$ & $\begin{array}{l}0 \\
+ \\
\pm\end{array}$ & : & $\begin{array}{l}0 \\
\infty \\
\infty\end{array}$ & $\stackrel{0}{ن}$ & in & S & $\begin{array}{l}0 \\
9 \\
2\end{array}$ & $\begin{array}{l}0 \\
\dot{2} \\
\infty\end{array}$ & \begin{tabular}{l|}
0 \\
$\dot{u}$ \\
$u$ \\
$u$
\end{tabular} & $\begin{array}{l}0 \\
\dot{u} \\
u\end{array}$ & : & $\begin{array}{l}0 \\
\dot{0} \\
0\end{array}$ & $\begin{array}{l}0 \\
\stackrel{0}{0} \\
\dot{0}\end{array}$ & 今. & 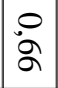 & 吕 & $\begin{array}{l}0 \\
\infty \\
\infty\end{array}$ & $\stackrel{\odot}{\stackrel{D}{\perp}}$ & $\begin{array}{l}0 \\
\stackrel{1}{u} \\
u\end{array}$ & $\stackrel{O}{\stackrel{I}{+}}$ & $\mid \stackrel{N}{\mathscr{O}}$ \\
\hline 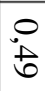 & $\mid \begin{array}{l}0 \\
0 \\
\infty \\
\infty\end{array}$ & is & 首 & 品 & in & \begin{tabular}{l|l} 
& \\
&
\end{tabular} & $\begin{array}{l}0 \\
8 \\
8\end{array}$ & $\begin{array}{l}0 \\
\dot{L} \\
\perp\end{array}$ & $\begin{array}{l}0 \\
\ddot{\varkappa} \\
\sigma\end{array}$ & $\begin{array}{l}0 \\
\ddot{u}\end{array}$ & $\begin{array}{l}0 \\
\stackrel{0}{\prime} \\
t\end{array}$ & $\begin{array}{l}\circ \\
8 \\
8\end{array}$ & \begin{tabular}{|l|}
0 \\
$\dot{3}$ \\
0
\end{tabular} & Oे & $\begin{array}{l}\circ \\
\dot{\alpha}\end{array}$ & $\begin{array}{l}0 \\
\dot{\mathbf{S}}\end{array}$ & \begin{tabular}{l|} 
\\
$\dot{\infty}$ \\
$\dot{\infty}$
\end{tabular} & $\stackrel{\circ}{0}$ & $\begin{array}{l}0 \\
\dot{u} \\
u\end{array}$ & $\stackrel{O}{\perp}$ & $\mathcal{N}$ \\
\hline$\stackrel{+}{ \pm}$ & \begin{tabular}{l}
0 \\
\hdashline \\
$\dot{0}$ \\
\end{tabular} & i & 兑 & ¿्र & : & 完 & $\begin{array}{l}0 \\
\dot{u} \\
u \\
u\end{array}$ & $\begin{array}{l}0 \\
\text { 出 } \\
\text { N }\end{array}$ & \begin{tabular}{|l|}
0 \\
$\dot{u}$ \\
$t$
\end{tabular} & \begin{tabular}{|c|} 
\\
$\dot{u}$ \\
$\infty$ \\
$\infty$
\end{tabular} & 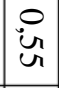 & $\begin{array}{l}0 \\
\text { ing } \\
\text { in }\end{array}$ & $\stackrel{\circ}{\circ}$ & ì & \begin{tabular}{l}
$\circ$ \\
\hdashline \\
$\dot{+}$ \\
\end{tabular} & $\ddot{8}$ & $\begin{array}{l}\circ \\
\dot{u} \\
\end{array}$ & $\stackrel{0}{0}$ & $\begin{array}{l}0 \\
\ddot{y} \\
0\end{array}$ & $\stackrel{O}{\ddots}$ & $\| \mathbb{E}$ \\
\hline 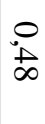 & $\infty$ & N & w & : & ğ & م & б. & $\stackrel{0}{i}$ & $\left|\begin{array}{l}0 \\
\dot{u} \\
\infty\end{array}\right|$ & $\begin{array}{l}0 \\
\text { in } \\
\infty\end{array}$ & $\begin{array}{l}0 \\
\dot{i} \\
0\end{array}$ & 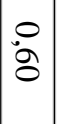 & $\stackrel{\circ}{9}$ & ò & $\begin{array}{l}0 \\
\dot{\alpha}\end{array}$ & O & : & $\stackrel{O}{\stackrel{N}{N}}$ & $\begin{array}{l}0 \\
\dot{w} \\
\end{array}$ & $\stackrel{\circ}{a}$ & 造 \\
\hline
\end{tabular}

Source: Machová and Kotlán (2013), Author's modifications 